\title{
Economic and Mathematical Modeling of Territorial Conditions for the Integration of Production Activities for the Extraction and Refining of Oil
}

\author{
${ }^{\square}$ Beilin Igor Leonidovich, ${ }^{2}$ Khomenko Vadim Vasilevich, ${ }^{3}$ Tagirov Marsel Sharipzyanovich, ${ }^{4}$ Zinurova \\ Raushaniya Ilshatovna, ${ }^{5}$ Gerasimov Alexander Viktorovich \\ ${ }^{1}$ Kazan Federal University, Institute of Management, Economics and Finance 8 Kremlyovskayastreet Kazan \\ 420008, Russian Federation \\ i.beilin@rambler.ru \\ 2,3,4,5 Tatar Scientific Research Institute of Agriculture, FRC Kazan Scientific Center, Russian Academy of Sciences, \\ Tatarstan Resp, Kazan, Orenburgskiy trakt, 48, Russian Federation \\ ispnecon@mail.ru \\ tatniva@mail.ru \\ rushazi@rambler.ru \\ gerasimov@kstu.ru
}

Received: 21st August 2020, Accepted: 14th September 2020, Published: 31st October 2020

\begin{abstract}
Territorial conditions for the integration of production activities for the extraction and processing of oil in the modern global world have became as a critical issue. The most striking feature of the placement of oil reserves is their high concentration in one relatively small region - the Persian Gulf basin. Here, in the Arab monarchies of Iran and Iraq, almost $2 / 3$ of proven reserves are concentrated, and most of them (more than $2 / 5$ of world reserves) are in three Arabian countries with a small indigenous population - Saudi Arabia, Kuwait and the United Arab Emirates. Even with the huge number of foreign workers who flooded these countries in the second half of the twentieth century, there are just over 20 million people, $0.3 \%$ of the world's population. Among the countries with very large reserves (more than 10 billion tons in each, or more than $6 \%$ of the world) are Iraq, Iran and Venezuela. These countries have long had a significant population and a more or less developed economy, and Iran and Iraq are the oldest centers of world civilization. Therefore, the high concentration of oil reserves in them does not look unfair, as in the three Arabian monarchies, where yesterday's illiterate and semi-wild nomads and herders are swimming in oil and petrodollars. The Organization for Economic Cooperation and Development includes 29 economically developed countries. It includes Australia, Austria, Belgium, Great Britain, Hungary, Germany, Greece, Denmark, Ireland, Iceland, Spain, Spain, Italy, Canada, Luxembourg, Mexico, the Netherlands, New Zealand, Norway, Poland, Portugal, the United States, Turkey, Finland, France, Sweden, Czech Republic, Switzerland, South Korea, Japan. The organization of the countries of oil exporters includes Indonesia, Iran, Iraq, Qatar, Kuwait, the United Arab Emirates, Saudi Arabia, Algeria, Libya, Nigeria, Venezuela. The aim of this work is to investigate present conditions particularly territorial conditions to production activities integration in order to the extraction and processing of oil which are the main factor in increasing the productivity of this sector of the economy.
\end{abstract}

\section{Keywords}

Economics, Econometrics, Economic and Mathematical Modeling, Theory of Economics, Regional Economy, Innovation Management.

\section{Introduction}

The three main oil producers in the world are Saudi Arabia, the United States, and the Russian Federation. These three countries account for a third of the oil produced in the world. These countries have maintained leadership over the past decades, but their positions in the group of leaders are constantly changing. Russia, which controlled $20 \%$ of the world market a decade ago, is no longer up to $10 \%$. In the US, mining, which by world standards seems huge, is actually small. For a country that burns and refines nearly a billion tons of petroleum products annually, four hundred million tons of mining is not a solution. Obviously, the future of the US economy is linked to the import of oil. Oil produced within the United States itself does not have a large impact on the world market. In Saudi Arabia, oil production can be called huge without exaggeration. Of the half a billion-ton production, the country "assimilates" only 50 million. It was not oil production that arose here in response to the needs of the economy for oil, but the oilconsuming economy itself was the latest response to the huge oil production that began to be carried out in the interests of external consumers (Enright 2003; Hufbauer et al. 2008; Beilin and Khomenko 2018). Oil-burning thermal power 
plants and desalination plants, which waste energy in order to build cities on the sand and grow wheat among the barren deserts of Arabia, petrochemical plants that process oil mainly not for local needs, but for subsequent export of products. But even with the stupid tranzhyrstva Saudi domestic consumption of oil is a drop in the sea of oil produced.

The country is the world's largest seller of oil, which largely determines the state of the world market for primary energy sources (Beilin 2017; Beilin 2016; Khmeleva and Bulavko 2016; Zadeh 2002; Ostergaard and Park 2015; Beilin 2017). Oil production and processing plays a key role in the development of many regions of the Russian Federation. On the territory of our country there are several areas with significant reserves of oil and gas, which are called oil and gas provinces.

These include both traditional production regions: Western Siberia, the Volga region, the North Caucasus, and new oil and gas provinces: in the European North (Timan-Pechora region), in Eastern Siberia and in the Far East. The fields of the West Siberian oil and gas province began to be developed in 1964. It includes the territory of the Tyumen, Tomsk, Novosibirsk and Omsk regions, the Khanty-Mansiysk and Yamalo-Nenets autonomous districts, as well as the adjacent shelf of the Kara Sea.

The main advantages of production in this region are the favorable structure of proven reserves and the predominance of oil with low sulfur content and other impurities. Prior to the discovery of deposits in Western Siberia, the Volga region occupied the first place in Russia in oil production. Due to its significant oil reserves, this region was named "Second Baku". The Volga-Ural oil and gas province includes several republics and regions of the Urals, the Middle and Lower Volga regions. In these regions, oil has been extracted since the 20s of the last century. Since then, more than 1,000 fields have been discovered in the Volga-Ural oil and gas province and more than 6 billion tons of oil been produced. This is almost half of the total volume mined in Russia.

\section{Methods}

Optimization problems are faced by economists, managers, financiers. The economic field of professional activity requires solving the tasks of staff planning, salary fund, drawing up optimal production plans, planning advertising campaigns, companies promoting products to the market, optimizing investments, etc. In addition, each of us in everyday life often solves the problem how to best meet the needs, while taking into account the available opportunities.

The compilation of economic and mathematical models of optimization problems is an excellent opportunity for economists to improve the quality of work (Yakupova et al. 2017; Beilin and Arkhireev 2011; Beilin et al. 2005; Tardy Yves 2010; Khmeleva et al. 2015; Al-Qahtani et al. 2008; Crowther and Haimes 2010; Dimitras et al. 1999). For various optimization problems, a large number of software tools have been developed, which are flexible tools for solving them. Its application requires the ability to write a mathematical model of the problem and enter it, and the optimal solution will be found using the tool. Linear optimization problems can be interpreted as follows: find the maximum (minimum) value of a linear optimization function with linear constraints on variables (Braginsky and Tadevosyan 2014; Deberdieva and Vechkasova 2015; Khazova 2015; Zobel and Khansa 2012; Rose 2001; Deberdieva and Shterbova 2015; Takafumi et al. 2009; Beilin et al. 2006). A linear function whose extremum is sought is called an objective function. Typical linear optimization problems are production planning, blending, staff planning, etc.

One of the founders of linear programming was Doctor of Physical and Mathematical Sciences, Professor LV. Kontorovich, a Soviet mathematician and economist, winner of the Nobel Prize in economics "for his contribution to the theory of optimal allocation of resources".

\section{Results and Discussion}

The North Caucasus region is the oldest and most explored oil and gas province in Russia, with a history of industrial oil production dating back more than 150 years. This province includes deposits located in the Stavropol and Krasnodar Territories, the Chechen Republic, the Rostov Region, Ingushetia, Kabardino-Balkaria, North Ossetia and Dagestan. The main deposits of this oil and gas province are in a late stage of development, heavily developed and flooded.

The Komi Republic and the Yamalo-Nenets Autonomous District are part of the Timan-Pechora oil and gas province (Beilin and Arkhireev 2009; Beilin and Arkhireev 2011; Vagizova et al. 2014; Alfares and Al-Amer 2002; Corrado and Fingleton 2012; Chen and Pouzo 2015). Targeted oil exploration and production is carried out here after the discovery of the first oil field - Chibyuskoye. A distinctive feature of the Timan-Pechora oil-producing province is the significant predominance of oil over gas. This region is considered promising from the point of view of hydrocarbon production, given the recently discovered large oil and gas fields in the coastal part of the Barents Sea.

The East Siberian oil and gas province, which so far has not been developed in the proper amount, is the main reserve for the future growth of reserves and the provision of oil and gas production in Russia. Remoteness, lack of population, 
lack of necessary infrastructure and severe weather and climatic conditions characteristic of these territories make it difficult to explore and extract oil. However, as deposits in traditional production areas are depleted, the development of the oil industry in Eastern Siberia is becoming a priority for oil workers (Leamer 2008; Fisher and LeSage 2013; Gibbons and Overman 2012; Hansen 2015; LeSage and Fischer 2008; LeSage and Parent 2007; Kleibergen and Paap 2006). A huge role in its decision is given to the construction of the East Siberia - Pacific Ocean oil pipeline, which will allow transporting the oil produced here to the ports of the Far East. The East Siberian oil and gas province is formed by the Krasnoyarsk Territory, the Republic of Sakha (Yakutia) and the Irkutsk Region.

The main proven reserves of oil and gas in the Far Eastern petroleum province are concentrated on Sakhalin Island and the adjacent shelf of the Okhotsk Sea. Even though oil has been extracted here since the 20s of the last century, active development began only 70 years after the discovery of large deposits on the northeast shelf of the island within the depths of the sea up to 50 meters. Compared with land deposits, they are distinguished by their large size, more favorable tectonic structure and higher concentration of reserves. Despite the fact that geologists see significant potential in this region, other territories within the Far Eastern oil and gas province are still poorly studied. Oil production geography:

1. Western Siberia district - located mainly in the Tyumen region. About $70 \%$ of the Russian oil is produced. In this database, the best quality oil in Russia. Deposits: Samotolor, Meshon, Ust-Balyk, Alexandrovskoye, Surgut.

2. Volga-Ural region. It takes the second place in Russia in oil production - $20 \%$ of the Russian oil production. Sulfur oil in this area requires refining, but it is cheap. The core of the Volga-Ural region are the deposits in Bashkortostan - Tuymazy and Ishimbay, in the Samara region - the Mukhanovskoye deposit, and in the Perm region - the Yarenskoye (Fig. 1).

3. Timan-Pechora region is located in the Komi Republic. Local oil is very valuable for the production of low thermal masses, necessary for the operation of mechanisms in the harsh conditions of our country.

4. The North Caucasus. Dagestan - Makhachkala. Chechen Republic - Grozny. Republic of Adygea - Maykop.

5. Eastern Siberia - Markovskoye deposit on the river Lia.

6. Far East in the north of Sakhalin - Okha.

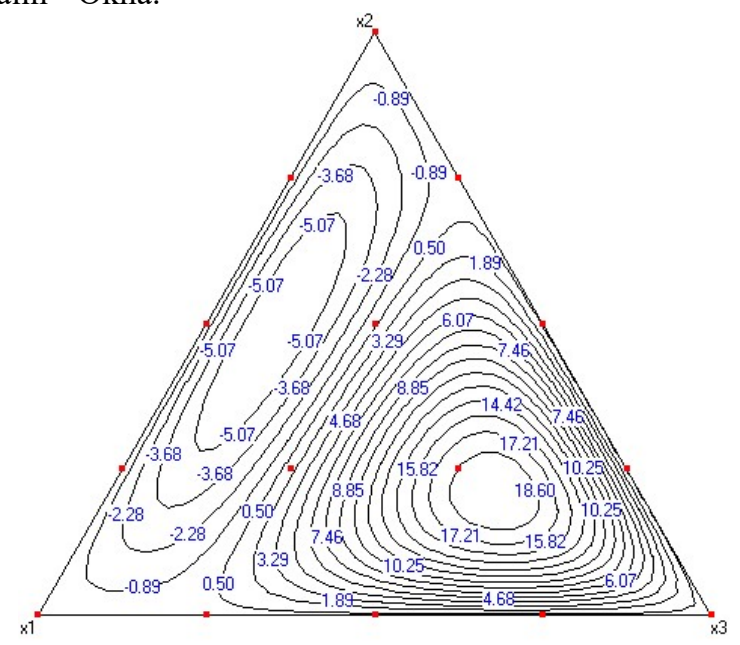

Fig.1: An Example of Optimization of the Territorial Conditions for the Integration of Production Activities for the Extraction and Refining of Oil in the Volga-Ural Region

Optimal conditions for territorial innovation industrial cluster integration in the field of oil production and oil and gas refining by many assessments exist in the Volga Federal District (Fig. 2). 


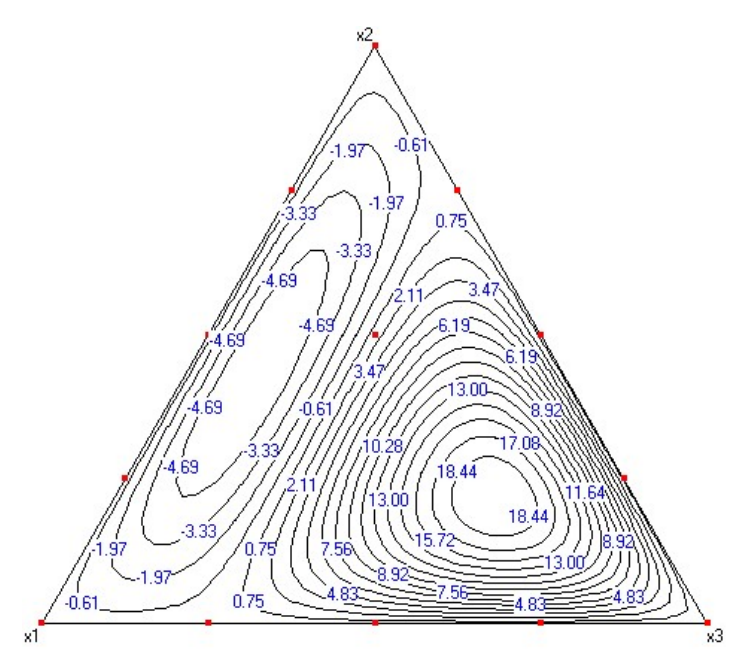

Fig.2: An Example of Optimization of the Territorial Conditions for the Integration of Production Activities for the Extraction and Refining of Oil in the Volga Federal District

Currently, the main centers of oil resources are in the Middle East and Latin America. In Russia, the main concentration of resources of this mineral is located in the Siberian Federal District, namely in Western Siberia, in contrast to the 19th century, when the Caucasus was the main center.

According to the energy strategy approved by the Ministry of Energy until 2030, in 10 years oil production in the country should grow to 530 million tons. This increase should be achieved mainly due to the commissioning of new fields in Eastern Siberia and the development of the continental shelf. However, companies indicate that under the current tax regime, which makes the development of hard-to-recover reserves unprofitable, it will not be possible to achieve this level of production. The largest East Siberian fields have already been introduced or are being commissioned; in the coming years, they will no longer compensate for the decline in oil production in traditional oilproducing regions - in Western Siberia. The prospects for the development of the Arctic shelf are also rather vague.

\section{Summary}

Experts point out that the amount of unexplored oil in Russia is many times higher than the amount that has been received during the whole period of its production. Therefore, in the long term, it is expected that new fields will be discovered, which will increase the amount of oil in the country, which will lead to its efficient development. The energy strategy approved by the Russian government until 2030 is ambitious, despite the crisis - it provides for a twofold, three-fold increase in oil and gas exports, a serious increase in their production and proven reserves, energy efficiency and energy saving; It is planned to attract 60 trillion rubles of investments for all this in the designated period.

\section{Conclusions}

Due to the implementation of the energy strategy, Russia must fully meet its future energy needs, and also strengthen its position in global markets for which demand will definitely be. The strategy is designed to replace the strategy until 2020. The revision of the main indicators needed in connection with the financial crisis. According to the document, by 2030, energy consumption per capita in the Russian Federation should grow by at least $40 \%$ compared with 2015 of motor fuel - by no less than $70 \%$. The forecast of the Ministry of Energy - 530 million tons of oil by 2030 - is quite realistic. Prospects, both in Eastern Siberia and on the shelf, are quite good. In connection with the crisis, oil production in Russia began to decline. But this does not affect the quality of petroleum products. But the forecasts are quite optimistic, and in the course of 15 years oil production in Russia should increase substantially.

\section{Acknowledgements}

The work is performed according to the Russian Government Program of Competitive Growth of Kazan Federal University. The article was prepared based on the results of research conducted within the framework of the state task under the leadership of the Federal Agency of Scientific Organizations of Russia, with the registration number: AAAA-A18-118031390148-1. 


\section{References}

[1] Alfares, Hesham, and Adnan Al-Amer. 2002. "An optimization model for guiding the petrochemical industry development in Saudi Arabia." Engineering Optimization 34(6): 671-687.

[2] Al-Qahtani, K., A. Elkamel, and K. Ponnambalam. 2008. "Robust optimization for petrochemical network design under uncertainty." Industrial \& engineering chemistry research 47(11): 3912-3919.

[3] Beilin, I. 2016. "Analysis of efficiency of the innovative project in the field of chemistry fuzzy logic." Journal of Economics and Economic Education Research 17(3): 177-185.

[4] Beilin, I. L. 2017. "Economic optimization in chemical enterprises." International Journal of Economic Perspectives 11(4): 670-677.

[5] Beilin, I. L. 2017. "Economic-mathematical modeling of the total costs of innovative chemical enterprise methods of fuzzy set theory." Journal of Engineering and Applied Sciences 12(19): 4865-4869.

[6] Beilin, I. L., and V. P. Arkhireev. 2009. "New copolymer products from cyclic carbonates and isocyanatecontaining compounds." Protection of Metals and Physical Chemistry of Surfaces 45(4): 450-454.

[7] Beilin, I. L., and V. P. Arkhireev. 2011. "Synthesis and structure of copoly (amide esters) based on cyclic carbonates and monofunctional isocyanates." Protection of Metals and Physical Chemistry of Surfaces 47(4): 478-483.

[8] Beilin, I. L., and V. P. Arkhireev. 2011. "The supermolecular structure of new copolymer products based on cyclic carbonates." International Polymer Science and Technology 38(1): 37-40.

[9] Beilin, I. L., and V. V. Khomenko. 2018. "Theoretical bases of project management in conditions of innovative economy based on fuzzy modeling." In Journal of Physics: Conference Series 1015(3): 032013..

[10] Beilin, I. L., V. P. Arkhireev, and S. S. Galibeev. 2005. "New copolymers of propylenecarbonate with controlled complex of properties." Plasticheskie Massy: Sintez Svojstva Pererabotka Primenenie 7: 12-15.

[11] Beilin, I. L., V. P. Arkhireev, and S. S. Galibeev. 2006. "Copolymerization of cyclic carbonates with isocyanates under anionic initiation conditions and structure of the new copolymers." Russian Journal of Applied Chemistry 79(1): 133-136.

[12] Braginsky, A., and G. Tadevosyan. 2014. How to avoid the "point of no return"'. Oil of Russia 3-4: 33-38. retrieved 17 February 2016.

[13] Chen, Xiaohong, and Demian Pouzo. 2015. "Sieve Wald and QLR inferences on semi/nonparametric conditional moment models." Econometrica 83(3): 1013-1079.

[14] Corrado, Luisa, and Bernard Fingleton. 2012. "Where is the economics in spatial econometrics?." Journal of Regional Science 52(2): 210-239.

[15] Crowther, Kenneth G., and Yacov Y. Haimes. 2010. "Development of the multiregional inoperability input-output model (MRIIM) for spatial explicitness in preparedness of interdependent regions." Systems Engineering 13(1): $28-46$.

[16] Deberdieva, E. M., and M. V. Vechkasova. 2015. "The competitiveness of domestic polymers: problems and development potential." Theory and practice of social development 19: 54-56.

[17] Deberdieva, E. M., and Y. V. Shterbova. 2015. "Prospects of development of oil-gas in the Tyumen region'." Economy and Entre-preneurship 10-2: 63-2.

[18] Dimitras, Augustinos I., Roman Slowinski, Robert Susmaga, and Constantin Zopounidis. 1999. "Business failure prediction using rough sets." European Journal of operational research 114(2): 263-280.

[19] Enright, Michael J. 2003. "Regional clusters: what we know and what we should know." In Innovation clusters and interregional competition, pp. 99-129. Springer, Berlin, Heidelberg.

[20]Fischer, Manfred M., and James P. LeSage. 2013. "A Bayesian space-time approach to identifying and interpreting regional convergence clubs in Europe." Paper presented at 53rd ERSA conference, Palermo: 27-31.

[21] Gibbons, Stephen, and Henry G. Overman. 2012. "Mostly pointless spatial econometrics?." Journal of Regional Science 52(2): 172-191.

[22] Hansen, Bruce E. 2015. "The integrated mean squared error of series regression and a Rosenthal Hilbert-space inequality." Econometric Theory 31(2): 337-361.

[23] Hufbauer, G.C., J.S. Schott, K.A. Elliott, B. Oegg, 2008. "Economic Sanctions Reconsidered.” Third edition. Peterson Institute For International Economics. Washington DC, 233 p.

[24] Khazova, T.N. 2015. "Petrochemical: missed opportunities, or leap into the future." Neftegaz.RU: Business Journal 4: 30-35. Khmeleva, Galina A., Ludmila V. Orlova, Olga A. Bulavko, Klim O. Kostromin, and Sayra K.

[25] Umerbaeva. 2015. "Identification of Perspective Transborder Clusters of Russia and Kazakhstan." Mediterranean Journal of Social Sciences 6(4): 302-312.

[26] Khmeleva, Galina, and Olga Bulavko. 2016. "From the 2008 to the 2014 crisis: response of the labor market of Russia's largest cities." International Journal of Environmental \& Science Education 11(4): 3791-3806. 
[27] Kleibergen, Frank, and Richard Paap. 2006. "Generalized reduced rank tests using the singular value decomposition." Journal of econometrics 133(1): 97-126.

[28] Leamer, Edward E. 1990. "Specification problems in econometrics." In Econometrics, pp. 238-245. Palgrave Macmillan, London.

[29] LeSage, James P., and Manfred M. Fischer. 2008. "Spatial growth regressions: model specification, estimation and interpretation." Spatial Economic Analysis 3(3): 275-304.

[30]LeSage, James P., and Olivier Parent. 2007. "Bayesian model averaging for spatial econometric models." Geographical Analysis 39(3): 241-267.

[31] Østergaard, Christian Richter, and Eunkyung Park. 2015. "What makes clusters decline? A study on disruption and evolution of a high-tech cluster in Denmark." Regional Studies 49(5): 834-849.

[32] Rose, Peter R. 2001. "Risk analysis and management of petroleum exploration ventures." Vol. 12. Tulsa, OK: American Association of Petroleum Geologists.

[33] Takafumi, Noguchi, T. Fminori, M. N. Kamran, M. C. Bernardino, and P. F. Alessandro. 2009. "Practical Equations for the Elatic Modulus of Concrete." ACI Structural Journal 106(5).

[34] Tardy, Yves. 1997. "Petrology of laterites and tropical soils." AA Balkema.

[35] Vagizova, Venera, Vadim Homenko, and Gulnaz Akhmetova. 2014. "The Volga region banking and real sectors interaction cluster initiatives." Investment management and financial innovations 11(4): 1334-141.

[36] Yakupova, N. M., S. J. Levachkova, E. I. Kadochnikova, and I. L. Beilin. 2017. "Measurement of cost factors: Evidence from trading companies." International Journal of Economic Perspectives 11(4): 794-802.

[37] Zadeh, Lotfi A. 2002. "Toward a perception-based theory of probabilistic reasoning with imprecise probabilities." In Soft Methods in Probability, Statistics and Data Analysis, pp. 27-61. Physica, Heidelberg.

[38]Zobel, Christopher W., and Lara Khansa. 2012. "Quantifying cyberinfrastructure resilience against multi-event attacks." Decision Sciences 43(4): 687-710. 